\title{
Opgøret om Ruslands arktiske udenrigspolitik
}

Morten Larsen Nonboe

Ruslands udenrigspolitik i det arktiske område er en blanding af samarbejde i folkerettens regi og forsøg på at hævde Ruslands position, eventuelt også med militære midler. Det viser modsætninger mellem målet om en multipolær verdensorden og indenrigspolitiske særinteresser

Begrebet 'Arktis' har flere betydninger. Geografisk kan regionen henvise til landene nord for polarcirklen, som omtrentligt følger den 66 . breddegrad nord om Island og gennem Canada, Danmark (Grønland), Finland, Norge, Sverige, Rusland og USA (Alaska). Disse lande udgør eksempelvis de otte faste medlemmer af Det Arktiske Råd.

Rusland foretrækker imidlertid at dømme ud fra officielle russiske dokumenter - en anden definition, som fokuserer på de fem arktiske kyststater med grænser mod det Arktiske Hav. I Ruslands Nationale Sikkerhedsråds arktiske strategipapir fra september 2008 hedder det fx, at "fem lande er placeret i det arktiske område - Rusland, Canada, USA, Norge og Danmark”. På baggrund af den globale opvarmnings effekt på isen i regionen har strategipapiret store forventninger til den fremtidige udnyttelse af området, som menes at indeholde op mod en femtedel af verdens uopdagede olieog gasforekomster. Strategipapiret forudser, at det arktiske område vil blive Ruslands vigtigste 'strategiske ressourcebase' i fremtiden og vil være i stand til at sikre Ruslands 'samfundsøkonomiske udvikling'.

Desuden lægges der i strategipapiret vægt på udnyttelsen af Nordøstpassagen nord om Rusland, som potentielt kan reducere omkostningerne for international skibstrafik be- 
tragteligt og bidrage til udviklingen af Ruslands arktiske egne.

\section{Fra kold krig til samarbejde}

Rusland har været aktiv i det arktiske område i århundreder. Særligt mod slutningen af det 19. århundrede begyndte det tsaristiske Rusland at vise interesse for områdets økonomiske og strategiske muligheder. Under Første Verdenskrig sendte Rusland i 1916 diplomatiske noter til sine allierede og de neutrale lande med krav på øerne ud for Ruslands nordlige kyster pga. deres beliggenhed.

Oktoberrevolutionen i 1917 ændrede ikke på strategien i området, og de bolsjevikiske myndigheder begyndte tidligt at håndhæve Sovjetunionens arktiske suverænitet. Med den britiske regerings stiltiende accept blev canadiske bosættere $\mathrm{fx}$ fjernet fra Wrangel Øen i det Arktiske Hav nord for Sibirien i 1924. Samtidigt udnyttede den sovjetiske ledelse aktivt højtprofilerede ekspeditioner i Arktis i forsøget på at skabe en sovjetisk identitet og national stolthed.

I 1926 fulgte Sovjetunionen Canadas eksempel fra 1907 og definerede sine besiddelser i det arktiske område ud fra den såkaldte sektorteori. Dermed blev det trekantede område fra Sovjetunionens nordøstligste og nordvestligste hjørner op til Nordpolen anset for at være en sovjetisk sektor. Den præcise juridi- ske status for de arktiske egne af Sovjetunionen forblev uklar frem til Sovjetunionens sammenbrud, men det var fra starten klart, at Sovjetunionen mente at have førsteret i området.

\section{Frygt for atomangreb}

Den kolde krig gjorde Sovjetunionen endnu mere restriktiv i forhold til det arktiske område, hvor Sovjetunionen og USA geografisk befandt sig nærmest hinanden. Sovjetunionen tillagde særligt regionen afg $\varnothing$ rende betydning efter 1959, hvor den amerikanske atomubåd Nautilus navigerede under Nordpolen og fik Sovjetunionen til at frygte et atomangreb fra det arktiske område. Både Sovjetunionen og USA investerede i de følgende år massivt i udviklingen af deres atomubåde $\mathrm{i}$ regionen, og den kolde krig medførte dermed en markant militarisering af det arktiske område.

Først med Mikhail Gorbatjovs Murmansk-tale i 1987 begyndte Sovjetunionen at vise en mindre restriktiv holdning i forhold til det arktiske område. Gorbatjov foreslog bl.a. at gøre Arktis til en 'fredszone' og opfordrede til militær nedrustning i regionen. Afspændingslinjen blev umiddelbart fortsat efter Sovjetunionens sammenbrud. I 1996 var Rusland fx med til at oprette Det Arktiske Råd, hvis mandat er at fremme "samarbejde, koordination og interaktion mellem de arktiske lande". 
Det følgende år ratificerede Rusland FN's havretskonvention fra 1982, som er det vigtigste folkeretlige grundlag for det arktiske område. Ifølge havretskonventionen har de arktiske kyststater fuld suverænitet i et område på 12 sømil $(22 \mathrm{~km})$ fra deres kyster. Desuden har hver kyststat automatisk en eksklusiv økonomisk zone på $200 \mathrm{sømil}(370 \mathrm{~km})$, hvor de har ret til ressourcerne under havoverfladen.

Den eksklusive økonomiske zone kan udvides til en vis grad, såfremt et land over for FN's kommission for kontinentalsoklens grænser kan påvise, at undergrunden geologisk er en naturlig forlængelse af landets kontinentalsokkel. I 2001 indleverede Rusland som det første arktiske land en anmodning om en forlængelse af sin eksklusive økonomiske zone til kommissionen. I alt gør Rusland krav på et område på omkring 1,2 millioner kvadratkilometer, hvilket svarer til størrelsen på Tyskland, Frankrig og Italien tilsammen.

Området er mindre omfattende end Sovjetunionens sektorkrav fra 1926, men FN's kommission for kontinentalsoklens grænser afviste ikke desto mindre Ruslands anmodning i 2002 pga. manglende videnskabelig materiale. Efterfølgende har Rusland indsamlet nye geologiske data med henblik på at indlevere en ny anmodning i 2013.

I den forbindelse gennemførte Rusland i 2007 en større arktisk ekspedition ved navn Arktika 2007 for nærmere at undersøge den arktiske havbund. Ekspeditionen indsamlede en række prøver fra havbunden og udførte med to mini-ubåde verdens første bemandede neddykning til bunden af Nordpolen. Her placerede en af mini-ubådene ved hjælp af en robotarm et stort russisk titaniumflag.

\section{Flagsætning på Nordpolen}

Flagsætningen afstedkom et forøget international fokus på Arktis og blev kraftigt fordømt fra især canadisk side. Den daværende canadiske udenrigsminister, Peter MacKay, udtalte fx: "Det her er ikke det 15. århundrede (...), man kan ikke bare gå rundt i verden og sige "vi gør krav på det her territorium' ". Det er dog langt fra entydigt, om den russiske flagsætning rent faktisk var et forsøg på at gøre krav på arktisk territorium uden for folkeretten og havretskonventionens rammer.

Trods indsamlingen af havbundsprøverne er forbindelsen mellem Ruslands hidtidige udenrigspolitik i området og Arktika 2007 nemlig forholdsvis uklar. Særligt organiseringen og finansieringen af Arktika 2007 afspejler de gådefulde forbindelser mellem Ruslands officielle udenrigspolitik i Arktis og flagsætningen i 2007.

Formelt blev Arktika 2007 organiseret af Instituttet for Oceanografi under Det Russiske Videnskabernes Akademi, men ekspeditionen blev 
senere autoriseret af en styrelse under den russiske regering. For at gennemføre ekspeditionen underskrev Instituttet for Oceanografi en kontrakt med den russiske Polarforskningsfond, som er en privat organisation etableret af Den russiske Forening af Polarforskere. Siden 1990 har denne forening været ledet af polarforskeren Artur Tjilingarov, som forekommer at spille en altafgørende rolle i forhold til flagsætningen i 2007.

Foruden sine polare aktiviteter tjener Tjilingarov som den russiske præsidents særlige polarrådgiver og repræsenterer Forenet Rusland i den russiske Statsduma, hvor han har fungeret som viceformand siden 1993. Tjilingarov er generelt fortaler for en offensiv russisk tilstedeværelse i Arktis, og han var personligt ombord på den mini-ubåd, som placerede det russiske flag på bunden af Nordpolen. To år før flagsætningen talte Tjilingarov på Forenet Ruslands sjette partikongres, hvor han opfordrede partiets ledere til aktivt at arbejde for at få den russiske regering mere aktivt involveret $\mathrm{i}$ arktiske anliggender. På den baggrund er Tjilingarovs udtalelser efter Arktika 2007 interessante.

\section{Russisk succes}

Her sagde Tjilingarov bl.a.: "Vi forsøgte at gøre vores regering opmærksom på problemet med at udvide Ruslands arktiske zone (...) og, som I ser, er det fuldstændigt lykkedes for os". Uklarheden om den russiske regerings involvering i Arktika 2007 afspejles også af finansieringen af ekspeditionen.

Ifølge Tjilingarov er det "værd at bemærke, at ekspeditionen ikke gennemførtes for offentlige midler". I stedet har Tjilingarov henvist til russiske forretningsmænd. Andre kilder peger i stedet på den svenske rigmand og eventyrer Frederik Paulsen, som deltog i Arktika 2007.

Manglen på offentlige midler kan synes tvivlsom, men under alle omstændigheder er usikkerheden omkring finansieringen interessant, fordi den russiske regering tilsyneladende ikke har ønsket på forhånd at kæde Arktika 2007 direkte sammen med Ruslands udenrigspolitik i regionen.

Efterfølgende har ledende russiske beslutningstagere også gjort sig store anstrengelser for at nedtone den udenrigspolitiske betydning af Arktika 2007, som de i stedet har hilst velkommen som et forskningsprojekt. Daværende præsident Vladimir Putin modtog fx Tjilingarov i privat audiens efter ekspeditionen, hvor han roste ekspeditionen og lovede, at Rusland også fremover ville være aktivt til stede i Arktis.

I januar 2008 tildelte præsident Putin desuden den højeste russiske udmærkelse, 'Den Russiske Føderations Helt', til Tjilingarov og to andre besætningsmedlemmer. Støtten fra præsidentadministrationen har 
dog været eksplicit begrænset til den videnskabelige side af Arktika 2007 og udførelsen af den første bemandede neddykning til bunden af Nordpolen. Efter den private audiens med Tjilingarov fremhævede præsident Putin således, at Arktika 2007 havde indsamlet nyt videnskabeligt materiale for at underbygge Ruslands krav i videre forhandlinger med de øvrige arktiske stater og i internationale organisationer.

På samme måde påpegede Putin efter overrækkelse af udmærkelserne til deltagerne i Arktika 2007, at Rusland indsamler nyt materiale, fordi Rusland ønsker at sikre en åben og objektiv dialog inden for de eksisterende internationale procedurer. Ruslands udenrigsministerium har også aktivt bestræbt sig på at nedtone betydningen af flagsætningen. Udenrigsminister Sergej Lavrov understregede eksempelvis i dagene efter flagsætningen Ruslands tilslutningen til havretskonventionen. Med implicit reference til den canadiske udenrigsministers kritik afviste Lavrov, at flagsætningen afspejlede et forsøg på at gøre krav på territorium uden for havretskonventionen.

Flagsætningen blev i stedet sammenlignet med det amerikanske flag på månen og bjergbestigeres flagsætning på Mount Everest. Fra officielt hold har ledende russiske beslutningstagere altså gjort sig store anstrengelser for at nedtone den udenrigspolitiske betydning af Arkti- ka 2007 og flagsætningen på bunden af Nordpolen.

\section{Indenrigspolitisk sigte}

Samtidigt tyder flere forhold på, at Arktika 2007 havde et klart indenrigspolitisk sigte. Særligt iøjnefaldende er forbindelsen til partiet Forenet Rusland, som Putin er formand for. Foruden Tjilingarov bestod besætningen på mini-ubåden, som placerede det russiske flag, således også af et andet af Forenet Ruslands medlemmer af Statsdumaen. Desuden efterlod ubåden ved siden af det russiske flag en tidskapsel, som bl.a. indeholdt et Forenet Rusland-flag.

Formanden for udenrigsudvalget i det russiske Føderationsråd, Mikhail Margelov, har offentligt betegnet placeringen af Forenet Rusland-flaget som 'et fremragende PR-træk fra hans partikolleger'. Formanden for Statsdumaen, det ledende medlem af Forenet Rusland, Boris Gryslov, har efterfølgende også hilst Arktika 2007 velkommen og understreget, at han var glad for, at medlemmer af Forenet Rusland deltog. Det er derfor oplagt at se en forbindelse mellem Arktika 2007 og valget til den russiske Statsduma, som fandt sted få måneder senere i december 2007.

Det er i den sammenhæng værd at bemærke, at en selvsikker russisk fremfærd ser ud til at være populær blandt de russiske vælgere. En meningsmåling foretaget $\mathrm{i}$ august 2007 viste, at mere end 70 procent støtte- 
de Arktika 2007, mens hele 90 procent var overbeviste om, at Rusland havde krav på selve Nordpolen.

Russiske politikere har derfor ligesom i Sovjetunionen gode muligheder for instrumentelt at anvende en aktiv russisk tilstedeværelse i Arktis til at skabe stolthed indadtil i Rusland og opbakning til den nuværende politiske ledelse.

\section{Arktiske enheder}

Den udfordrende adfærd i det arktiske område vækker også genklang blandt såkaldte siloviki, folk i de russiske sikkerhedstjenester og militær. Tjilingarov har bl.a. en vigtig støtte i den tidligere leder af den russiske sikkerhedstjeneste FSB og nuværende formand for Ruslands Nationale Sikkerhedsråd, Nikolaj Patrusjev. I januar 2007 ledsagede Patrusjev Tjilingarov på en højt eksponeret helikopterrejse til Sydpolen, og Patrusjev har offentligt støttet Tjilingarovs linje i Arktis. Patrusjev har udtalt, at de andre arktiske kyststater vil drive Rusland væk fra Arktis, hvis Rusland ikke snart handler.

Også blandt flere militære ledere er der støtte til en konfronterende russisk udenrigspolitik i området. Den øverstbefalende for den russiske flåde, admiral Vladimir Vysotskij, har udtalt, at mens der i øjeblikket er fred og stabilitet i Arktis, kan det "ikke udelukkes, at der i fremtiden vil ske en magtbaseret revision, inkluderende væbnet intervention".
Chefen for det russiske forsvarsministeriums centrale kamptræningsdirektorat, generalløjtnant Vladimir Sjamanov, har ligeledes påpeget, at hans direktorat er ved at færdiggøre træningsplaner for enheder, som potentielt kan anvendes på kampmissioner i Arktis.

Den konfronterende retorik fra visse kredse i Rusland afspejles også i officielle russiske dokumenter. Det Nationale Sikkerhedsråds arktiske strategi fra 2008 opfordrer blandt andet til, at Rusland opretter særlige arktiske enheder med henblik på at sikre Ruslands militære sikkerhed i området. Ruslands nationale sikkerhedsdoktrin fra 2009 nævner ligeledes med direkte reference til Arktis, at international politik i fremtiden primært vil omhandle besiddelse af energiressourcer. Anvendelse af militær magt til at afgøre energistridigheder kan ifølge sikkerhedsdoktrinen ikke udelukkes.

De dystre forudsigelser er til en vis grad blevet fulgt op af en øget militær tilstedeværelse i regionen. Siden slutningen af 2007 har Rusland fx gennemført flyvninger med strategiske bombefly over det arktiske område. De strategiske bombefly er ved flere lejligheder kommet særligt tæt på canadisk luftrum, hvilket har fået den canadiske premierminister, Stephen Harper, til at tale om 'mere og mere aggressive russiske handlinger'.

Ruslands Nordlige Flåde i Murmansk, som allerede udgør to tredjedele af den russiske flåde, har også 
fået tilført yderligere ressourcer i de senere år med henblik på at styrke Ruslands arktiske tilstedeværelse. Den konfronterende retorik fra visse militære ledere og ressourcetilførslen til det russiske militær afspejler imidlertid ikke nødvendigvis det russiske militærs faktiske sikkerhedsvurdering af det arktiske område.

Tværtimod kan militariseringen synes at være et mål i sig selv for det russiske militær, som siden Sovjetunionens sammenbrud har oplevet dramatiske nedskæringer. Det er derfor sandsynligt, at der bag den konfronterende retorik ikke mindst gemmer sig et pragmatisk forsøg på at sikre ressourcetilførslen og undgå yderligere nedskæringer. På samme måde har de russiske grænsetropper, som bl.a. står for sikringen af Ruslands vidtstrakte arktiske grænser, siden 2003 været underlagt FSB.

Såkaldte siloviki i de russiske sikkerhedstjenester som Patrusjev kan derfor også have en klar egeninteresse i en anspændt situation i det arktiske område. Indenrigspolitiske hensyn som folkelig politisk opbakning til Forenet Rusland og budgetmæssige interesser hos det russiske militær og de russiske sikkerhedstjenester kan på den baggrund have betydelig indflydelse på den russiske adfærd i det arktiske område. Der er derfor god grund til at medtænke den indenrigspolitiske dimension bag russisk udenrigspolitik i Arktis.

Det russiske udenrigsministerium har således også i perioden efter
Arktika 2007 fortsat anstrengelserne for at nedtone flagsætningen og bekræfte Ruslands intention om at løse det arktiske områdes fremtid inden for de eksisterende folkeretlige rammer.

Allerede få måneder efter Arktika 2007 deltog russiske embedsmænd fx i et møde i oktober 2007 mellem de arktiske kyststater i Oslo. Her enedes kyststaterne om, at den eksisterende folkeret baseret på havretskonventionen udgjorde et tilstrækkeligt grundlag for løsning af eventuelle konflikter i det arktiske område. Samtidigt understregede kyststaterne deres støtte til fortsat samarbejde i Arktis.

\section{Ilulissat-topmødet}

Umiddelbart efter mødet i Oslo begyndte Danmark at forberede det første topmøde mellem kyststaterne på ministerniveau. Topmødet fandt sted i den grønlandske by Ilulissat i maj 2008 og resulterede i Ilulissatdeklarationen, som igen understreger kyststaternes støtte til havretskonventionen og det eksisterende folkeretlige grundlag for Arktis. Ligesom i Oslo påpeger kyststaterne $\mathrm{i}$ Ilulissat-deklarationen, at det eksisterende folkeretlige grundlag er tilstrækkeligt for løsning af eventuelle uenigheder, som de udtrykker deres intention om at afgøre på fredelig vis.

Desuden fremhæver Ilulissat-deklarationen kyststaternes særstatus 
og deres suveræne rettigheder i det arktiske område.

Rusland deltog begejstret i Ilulissat-topmødet, der ifølge udenrigsminister Lavrov styrkede 'tilliden og samarbejdet mellem de arktiske kyststater'. Faktisk fremhævede udenrigsminister Lavrov Ilulissat-topmødet som et forbillede for samarbejde andre steder. Ruslands entusiastiske opbakning til samarbejdet mellem de fem kyststater inden for folkerettens rammer synes ikke mindst at skyldes Ilulissat-deklarationens fokus på kyststaternes særstatus og deres suveræne rettigheder.

\section{Multipolær verden}

Betoningen af nationalstaterne og deres suveræne rettigheder er i god overensstemmelse med Ruslands udenrigspolitiske målsætning om at skabe en multipolær verden baseret på folkeret og suverænitetsprincippet. Rusland er derfor varsom med at krænke de folkeretlige spilleregler i det arktiske område for ikke at underminere Ruslands overordnede udenrigspolitiske ambitioner. Samtidig betyder de arktiske kyststaters særstatus, at Rusland ikke marginaliseres i forhold til de øvrige fire kyststater, som alle er medlemmer af NATO.

Særligt udelukkelsen af NATO fra det arktiske område er af stor betydning for Rusland. Ruslands nye udenrigspolitiske program, som angiveligt blev lækket i maj 2010, anbe- faler, at Rusland skal 'modvirke en bred internationalisering' af Arktis. NATO og EU nævnes her eksplicit som aktører, som skal holdes ude af regionen, fordi de er ' $i$ stand til at skade Ruslands naturlige konkurrencefordele i Arktis'.

Rusland har derfor samlet set en klar interesse i samarbejdet mellem de arktiske kyststater for at fremme Ruslands udenrigspolitiske målsætning om en multipolær verdensorden baseret på folkerettens suverænitetsprincip og forhindre en internationalisering af regionen. Senest viste Rusland sin fortsatte støtte til kyststatssamarbejdet på udenrigsministermødet i Chelsea i Canada i marts 2010. Her betonede kyststaterne endnu engang 'det omfattende folkeretlige grundlag' for det arktiske område og kyststaternes særlige rolle. Endeligt er det værd at bemærke, at støtten til et folkeretligt funderet samarbejde mellem de arktiske kyststater ikke alene fremhæves udadtil.

Internt i Rusland understreges Ruslands interesse heri også fra officielt hold. Det arktiske strategipapir fra Ruslands Nationale Sikkerhedsråd nævner fx 'bevarelsen af Arktis som en freds- og samarbejdszone' som en af Ruslands nationale interesser i regionen. Strategipapiret anbefaler af den grund, at Rusland skal sikre et gensidigt fordelagtigt samarbejde i Arktis baseret på folkeretten.

Ruslands udenrigspolitik i Arktis 
fremstår samlet set som et kompromis mellem Ruslands overordnede udenrigspolitiske målsætninger på den ene side og stærke indenrigspolitiske og budgetmæssige særinteresser på den anden side. Særligt officielle russiske dokumenter som det arktiske strategipapir giver indtryk af at afspejle uoverensstemmelserne mellem de forskellige interesser. Flere af dokumentets passager kan derfor ofte synes modstridende.

\section{Aggressiv retorik}

Den russiske ledelse forekommer omhyggeligt at afveje de forskellige interesser, men som møderne i Oslo, Ilulissat og Chelsea viste, har Ruslands overordnede udenrigspolitiske ambitioner indtil videre haft førsteprioritet. De indenrigspolitiske særinteresser vil imidlertid formentligt også fremover bidrage til ustabilitet i Ruslands udenrigspolitik i Ark- tis, og den mere aggressive retorik kan undertiden findes på højeste niveau.

Så sent som i marts 2010 påpegede præsident Dmitrij Medvedev, at "der har været forsøg på at begrænse Ruslands adgang til udforskning og udvikling af de arktiske ressourcer”. Medvedev tilføjede på den baggrund, at Rusland skal være parat til at forsvare sine krav i området i den tiltagende konkurrence med andre magter. Opgøret om Ruslands arktiske udenrigspolitik er derfor stadig et uafsluttet kapitel.

Morten Larsen Nonboe er ph.d. studerende ved Institut for Statskundskab, Aarhus Universitet med Ruslands politik for de arktiske områder som forskningsprojekt. Han har studeret $i$ Rusland og andre SNG-lande og det seneste år last russisk og østeuropaiske studier ved Oxford Universitet. 